Article

\title{
Communion, Care, and Leadership in Computer-Mediated Learning during the Early Stage of COVID-19 ${ }^{\dagger}$
}

\author{
Živilè Sederevičiūtè-Pačiauskienè ${ }^{1, *}$, Ilona Valantinaitè ${ }^{1}$ and Romualdas Kliukas ${ }^{2}$ \\ 1 Faculty of Creative Industries, Vilnius Gediminas Technical University, LT-10223 Vilnius, Lithuania; \\ Ilona.valantinaite@vilniustech.lt \\ 2 Faculty of Civil Engineering, Vilnius Gediminas Technical University, LT-10223 Vilnius, Lithuania; \\ romualdas.kliukas@vilniustech.lt \\ * Correspondence: zivile.sedereviciute-paciauskiene@vilniustech.lt; Tel.: +370-679-58289 \\ + An early version of the manuscript has been presented at the 2021 ICA Virtual Conference, Instructional and \\ Developmental Communication Division.
}

Citation: Sederevičiūtè-Pačiauskienè Ž.; Valantinaitè, I.; Kliukas, R. Communion, Care, and Leadership in Computer-Mediated Learning during the Early Stage of COVID-19.

Sustainability 2021, 13, 4234. https: / / doi.org/10.3390/su13084234

Academic Editors: Francisco Javier Hinojo Lucena, Juan Manuel

Trujillo Torres, Antonio José

Moreno Guerrero and Carmen Rodríguez Jiménez

Received: 13 March 2021

Accepted: 8 April 2021

Published: 10 April 2021

Publisher's Note: MDPI stays neutral with regard to jurisdictional claims in published maps and institutional affiliations.

Copyright: (c) 2021 by the authors. Licensee MDPI, Basel, Switzerland. This article is an open access article distributed under the terms and conditions of the Creative Commons Attribution (CC BY) license (https:// creativecommons.org/licenses/by/ $4.0 /)$.

\begin{abstract}
This qualitative inquiry explores how, during the early stage of the COVID-19 pandemic in Lithuania (European Union), the stakeholders in the education system-university teachers, general education teachers, students, and children's parents-coped with the encountered challenge and what was important to them under the changed conditions. This paper uses a communication management objective to describe how participants in the education system responded to the emerging distance learning situation and its challenges. The phenomenographic research approach was chosen to carry out the qualitative study. The 37 interviews from higher education teachers, university students, school teachers, and parents of minor school-aged children were conducted during the early stage of COVID-19 quarantine. The research allows for concluding that, after a successful transition to distance learning, the dimensions of communion and supportive collaboration acquired importance among stakeholders in education. Starting new activities, a need for communion and mobilization for joint activities under the crisis emerged. The research showed that the adaptation period was necessary at the beginning of these new activities. Competent leadership was expected from the teacher. Additionally, the preparation of all the actors in the education process was needed. The data offer a window into the dynamics of online teaching in crisis and experiences with a new activity that are key to success. Although research on technology-mediated learning has increased in recent years, it still lags behind developments in practice.
\end{abstract}

Keywords: technology-mediated learning; communion; supportive collaboration; teacher-student communication; pandemic

\section{Introduction}

In the face of the coronavirus pandemic, the whole world has been coping with partial or complete social isolation. The education system has been affected substantially. Online teaching and learning have become the "new normal" [1]. Distance education requires exceptional arrangements, abilities, and IT skills in addition to smart devices and applications that enable videoconferencing communication [2]. Distance learning for the majority of stakeholders in the education system was a new experience. Even experienced university teachers or school teachers encountered challenges, whereas parents got an additional load. The change caused by the pandemic affected and impaired the systems and processes that universities and school leaders were used to in order to lead and manage organizational performance, and it created barriers to existing mechanisms for providing moral, social, personal, and professional support and motivation to their staff [3]. There is much agreement among communication and leadership scholars and practitioners that crises disrupt and derail organizational practices, threaten individual and institutional reputations, and require rapid responses [4]. Having faced the crisis 
caused by the pandemic, the education system reacted and introduced measures to ensure its functioning rather quickly. However, the quarantine highlighted the weak sides of education and opened up new possibilities.

In this article, the researchers aimed to analyze the reflections of actors in the education system on online learning at the very beginning of the COVID-19 pandemic, approaching a rapid transition to distance teaching as a new activity for all stakeholders in education: university teachers, teachers, students, and parents of minor school-aged children. The lockdown caused by the COVID-19 pandemic is seen as a crisis following the theory of Estes [5], who states that "crises are socially constructed as a consequence of social perception and definition; that is, a crisis may be said to exist if it is perceived to exist." This perspective is echoed by Voss and Lorenz [6] in their description of a constructivist understanding of crisis as one that "privileges, not the objective threat but rather stakeholders" perception of the situation as a crisis. Mitroff and Coombs $[7,8]$ indicate that internal and external stakeholder perceptions are critical during a crisis. Crises are more accessible to intervention at their peak, and may be resolved in adaptive or maladaptive ways [9]. The researchers assume that elements that help to focus and concentrate at the beginning of a crisis are among the essential milestones while creating successful activities. The global health crisis was used as a catalytic moment to rethink the students, teachers, and parents' perception of online learning in a changed situation. The novelty of this study is the possibility for looking at distance learning at the beginning of the crisis in today's context, where technology makes it possible to ensure distance communication between educational actors. The study showed what dimensions emerge in distance learning when technological challenges are not the main problem.

\section{Background}

Before the pandemic-caused quarantine, higher education schools in Lithuania, an EU member country, just like schools worldwide, were implementing distance teaching. However, it was a part of usual teaching. Naturally, the transition to entirely online teaching created many challenges in all educational institutions: school and university teachers, students, and pupils learned to master new technology-mediated tools and environments, thought over assignments and tests, and had to get used to a new work routine. With a reduction of interaction in learning, actors in the education system lived through the crisis and solved the problem related to the shortage of social relations in their way.

Living in the background of constant educational reforms, university and school teachers had encountered several challenges before the pandemic hit. The necessity to use new technologies, the gap between the literacy of teachers and students in media and technologies, and differences in generational communication introduced certain insecurity among teachers. The mistrust of society in higher education was also among these challenges [10], including increased scrutiny from a wide array of internal and external audiences [11]; a concerning and uncertain financial outlook [12]; and ongoing issues related to access, affordability, and adequate job preparation for students [4].

Teaching is an emotionally challenging profession, sometimes resulting in high teacher stress, burnout, and attrition. Next to administrative workload [13,14], a problematic teacher-student relationship is a well-known contributor to negative emotions, decreased work engagement, and increased emotional exhaustion [15-17]. The new activities introduced because of the pandemic enhanced this situation. Communication at a distance became a challenge to teachers and pupils when interpersonal communication, which served as the basis for relations, decreased [18]. A crucial role of teacher-student relationships in the quality of teaching and learning has been demonstrated in many studies. The results showed teacher-student relationships to be associated with student cognitive learning outcomes and motivation $[15,19,20]$, and with teacher well-being [15,21].

Although the research shows that adaptation to remote work from home is relatively easy and fast [22], the researchers point out some disadvantages, such as the lack of coaching; the loss of social relationships; or the risk that the person will not be able to disconnect 
from work during their rest and leisure time because, being online, they can be contacted at any time [23]. These factors influence the quality of online teaching and continuance satisfaction. Another aspect that is relevant to the education community embraces the quality of distance learning. The use of online learning alone can be insufficient to meet the needs of faculty members and students [1]. Students have mixed feelings about whether online learning can nurture the knowledge and skills necessary for their career goals [24]. Smoyer et al. [18] states that interactive technologies may increase students' engagement and stimulate the human interaction essential to student learning and practice.

The sudden shift from classroom-based to remote learning had a significant effect on teachers, students, and parents, requiring swift adaptation to the digital platforms' features thrust upon them. Studies report successful cases of parents' involvement in distance learning and child support [3]. However, it is a new experience and responsibility for parents. Therefore, their views on this new activity are essential in planning the next steps. The process is a complicated practice that needs all stakeholders' considerable efforts to achieve the educational objectives successfully. This necessitates a well-qualified lecturer who can perfectly cope with this new method, well-motivated and skilled students who can also deal with this new method right [25], and the positive attitude of parents.

Therefore, it was relevant to identify how university teachers, students, school teachers, and children's parents felt when, in a crisis, they had to change their usual routine to teach and learn without such key components of teaching, i.e., face-to-face contact with learners, instant reflection, and colleague community. The research on how actors in the education system perceive/live through the situation of distance learning at the beginning of lockdown will allow for making insights not only into the success of the transition to distance learning but also foreseeing what is important for research stakeholders at the beginning of the new activity and crisis. The research can be of practical use to education leaders at all levels. Individuals with formal and informal leadership responsibilities can shape the conditions through which others experience a situation-and, therefore, may influence others to experience and treat specific moments and events as crises [4].

Although the COVID-19 pandemic is a global issue, the response needs to be local [26], including our interactions with others and the systems that bind us [27]. Therefore, this small-scale research on the attitude of actors in education in a small EU country can supplement the scientific discourse seeking to prepare for and recover from crises.

\section{Materials and Methods}

The first quarantine due to the COVID-19 pandemic in Lithuania was announced on 14th March 2020. Following which, the whole education system had to start distance learning unexpectedly. Higher and general education schools did not implement teaching for two weeks and used this period for preparation for it. Since the education system actors had accumulated different experiences in distance work or did not have any, this transition period was critical. It highlighted the aspects that were crucial to a person. Participants with different preparation and with different attitudes entered online teaching/learning. Therefore, it was decided to carry out a quick and general overview of stakeholders' attitudes in the education system towards the changed situation. The research goal was to disclose the attitude of actors in education (university teachers, university students, school teachers, and children's parents) towards distance teaching/learning at the beginning of quarantine due to the pandemic.

The research question: What is most important while organizing distance studies during the isolation period due to the pandemic?

The research design. The phenomenographic research approach was chosen to carry out the study. The research was carried out at the beginning of the quarantine due to the COVID-19 pandemic, i.e., from 3-16 April 2020, soon after online teaching was introduced. The 36 interviews ranged from 15 to $43 \mathrm{~min}$, with an average time of approximately $24 \mathrm{~min}$, resulting in more than $900 \mathrm{~min}$ of data. The research data were recorded with the consent of informants. The interviews were conducted and recorded via phone. The 
interviews were conducted until the researchers reached a point of saturation for the study overall [28]. The purposive sampling was applied, choosing participants/stakeholders in the education system with different expertise in distance learning, of different age, gender, and different pedagogical qualifications [29]. Such a sampling provided the researchers with the possibility of selecting meaningful cases and collecting more extensive data [30]. The total gender balance could not be achieved. However, the selected ones reflected the statistical situation in Lithuania. The majority $(88 \%)$ of general education school teachers are women. In vocational training institutions, women accounted for 69 percent; for 67 percent in colleges; and for 53 percent in universities.

The interview was taken from eight university teachers, one college teacher, one assistant professor, three Ph.D. student lecturers, one lecturer without a degree, and three associate professors. The teachers' age was from 26 to 59 years old. The amount of experience working in a higher education institution was from 6 to 30 years (two with 9 years of experience, four with 12-19 years of experience, and three with 20-30 years of experience). Six women and three men took part in the interview.

Eight teachers participated in the interview: two teachers from a vocational training center, one from a primary school, one from a gymnasium, two from a private secondary school, and one from a state secondary school. Teachers ranged in age from 36 to 57 years old. Work experience was from 15 to 35 years. Five teachers qualified as a headteacher, and three qualified as a methodologist, which is the highest possible qualification for a teacher in Lithuania. Only women participated in the study. Teachers represented various subjects taught: food technology (vocational training), hairdressing (vocational training), primary education, English, art and technology, music, and Lithuanian language.

Ten students took part in the study: four students from colleges (professional bachelor's degree) and six undergraduate students from universities. These were four first-year, three second-year, and three third-year students, with seven women and three men aged 19 to 22. Five students were from Kaunas town, and five from Vilnius.

Nine parents of the students participated in the study: two fathers and seven mothers. Two of them had professional bachelor's degrees, one had a university bachelor's degree, five had a master's degree, and one had a doctorate degree. Three parents had three children, two parents had two children, and four parents had one child. Their children attended grades 1 to 11 (aged from 7 to 18). The informants were from five Lithuanian towns.

The purposeful sampling during the phenomenographic research reveals a diversity of investigated experiences [31,32]. The research sample included nine higher education teachers (aged 29-59 years), ten university students (aged 18-23), eight school teachers (aged 36-57), and nine parents of minor school-aged children (aged 32-53) who helped their children to learn online during the lockdown. The research participants were assigned codes: university teacher $1-\mathrm{UT} 1$, university teacher 2 -UT2, etc.; student $1-\mathrm{S} 1$, student 2 $\mathrm{S} 2$, etc.; school teacher $1-\mathrm{ST} 1$, school teacher $2-\mathrm{ST} 2$, etc.; and parent $1-\mathrm{P} 1$, parent $2-$ $\mathrm{P} 2$, etc.

The researchers in this article analyze how actors in education perceive the very phenomenon of online learning during the pandemic-caused quarantine when they had to engage in a new activity very quickly. The question "What is most important while organizing distance studies during the isolation period due to the pandemic?" was asked of all the informant groups. Clarifying questions were asked during the interview, and if necessary, the informants were asked to clarify what they meant.

The phenomenographic research method was used to process the data. Phenomenography investigates the qualitatively different ways in which people experience phenomena. The research goal was not to generalize experiences but to present a variety of aspects that characterize experience in distance teaching/learning [33,34]. The results of phenomenographic research allowed for identifying and characterizing individual and subjective peculiarities and ways of perceiving the experienced phenomenon, showing their interrelations, and disclosing the relationship of an individual with the surrounding world $[35,36]$. 
Phenomenography is frequently applied to investigate teacher-student attitudes towards learning $[37,38]$. The aim was to carry out a descriptive, exploratory study where the variation-based generalization was performed [39]. Therefore, when summarizing the data, we focused on the reflection of the phenomenon under study, rather than theorization.

The data were analyzed following seven steps: (1) familiarization (the text is read, content is learned, and technical mistakes are eliminated), (2) compilation (the most significant elements in the responses of every informant are identified), (3) reduction (the essence of every more extended response or dialogue is searched for), (4) grouping (responses are grouped according to categories), (5) preliminary comparison of categories (boundaries among categories are established), (6) naming (categories are named), and (7) contrastive comparison (categories are compared, their differences are highlighted) [40]. The coder reliability check, when two researchers were independently coding the transcribed texts of all the interviews and comparing the received categories with each other, was conducted. The dialogic reliability check was done through researchers' discussions [41]. The "critical friend" method was used to assure rigor, and focused on a reflective approach [42]. The role of the critical friend is "to provide a theoretical sounding board to encourage reflection upon, and exploration of, multiple and alternative explanations and interpretations as these emerged in relation to the data and writing [43]. Validation was done by verifying the findings during the research process with continual checks of the credibility, plausibility, and trustworthiness of the findings [44]. Communicative validity checks were not carried out, as the study aimed not to capture a particular individual's understanding, but to capture the range of understandings within a particular group [41]. The authors followed the approach that the outcomes might then be judged in terms of the insight they provide into more effective ways of operating in the world [45]. A pragmatic validity check was performed, providing the recommendations to the teachers and institutions' executives in the discussion section.

Ethical issues were carefully considered and addressed. All interviews were anonymous and voluntary to ensure that all respondents felt comfortable in this sensitive lockdown time. The whole process met the General Data Protection Requirements (GDPR).

\section{Results}

The analysis of research data allowed for distinguishing seven categories that make up a hierarchically structured space of results. The identified categories revealed what was important to the actors in Lithuania's education system (university teachers, university students, school teachers, parents of minor students) at the beginning of organizing distance teaching/learning (Table 1). In the in-depth interviews, the actors in the education system, who unexpectedly found themselves in situations where distance learning became inevitable, disclosed the aspects of organizing distance learning of importance to them, and did not single out one as the most important.

Need of time for adaptation. Lithuanian higher and general education schools introduced distance teaching approximately two weeks after the start of quarantine. Higher education and school teachers noticed that, at the beginning of a new activity, mainly if little time was allocated to adaptation, they lacked self-confidence. Actors in the education system linked the period of preparation with adaptation, which was meant for psychological and professional preparation for the new activity, "well, the most important thing probably is good preparation of teacher $\langle\ldots .>$ I think that the decision to give two weeks for students as well as teachers to prepare was good. Preparation is essential because when eight years ago, I had to start to teach online. It was like jumping into the water, into the cold sea, when you had to clarify how to teach. The distance education center employees helped me then, but now there are a lot of ways to get help, recommendations, and various information. When I started teaching, there were fewer possibilities, or I was not able to find them. So, the support to the teacher is important" (UT 4). 
Table 1. Significant aspects of distance learning, which were disclosed by the stakeholders in the Lithuanian system of education at the beginning of the quarantine due to the COVID-19 pandemic (prepared by the authors following the methodology by Kinnunen et al. [46]).

\begin{tabular}{|c|c|c|c|c|}
\hline Category & $\begin{array}{l}\text { How Prerequisites } \\
\text { for Successful } \\
\text { Distance } \\
\text { Teaching/Learning } \\
\text { are Perceived }\end{array}$ & The Research Focus & $\begin{array}{c}\text { The } \\
\text { Dominating } \\
\text { Aspect }\end{array}$ & . \\
\hline $\begin{array}{l}\text { Time for } \\
\text { adaptation }\end{array}$ & $\begin{array}{l}\text { Influence of fact, } \\
\text { character, and way of } \\
\text { information } \\
\text { (non)presentation on a } \\
\text { person's disposition } \\
\text { to act }\end{array}$ & $\begin{array}{c}\text { How does } \\
\text { appropriate } \\
\text { communication } \\
\text { during the } \\
\text { adaptation period } \\
\text { impact the further } \\
\text { development of new } \\
\text { activity? }\end{array}$ & $\begin{array}{l}\text { Actors in the } \\
\text { education } \\
\text { system }\end{array}$ & 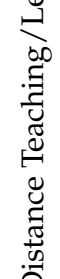 \\
\hline Communion & $\begin{array}{l}\text { Impact of the state } \\
\text { of communion }\end{array}$ & $\begin{array}{l}\text { How is communion } \\
\text { created, which turns } \\
\text { into a common } \\
\text { goal-oriented } \\
\text { activity? }\end{array}$ & $\begin{array}{l}\text { Actors in the } \\
\text { education } \\
\text { system }\end{array}$ & 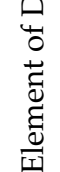 \\
\hline $\begin{array}{l}\text { Positive } \\
\text { attitudes }\end{array}$ & $\begin{array}{c}\text { Influence of personal } \\
\text { disposition and } \\
\text { behavior on the } \\
\text { development of } \\
\text { distance } \\
\text { teaching/learning }\end{array}$ & $\begin{array}{l}\text { How do the } \\
\text { personal attitudes of } \\
\text { the actors in } \\
\text { education influence } \\
\text { the development of } \\
\text { new activities? }\end{array}$ & $\begin{array}{l}\text { Actors in the } \\
\text { education } \\
\text { system }\end{array}$ & 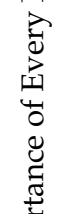 \\
\hline $\begin{array}{l}\text { Supportive } \\
\text { collaboration }\end{array}$ & $\begin{array}{l}\text { Circulation of } \\
\text { information creates an } \\
\text { atmosphere of } \\
\text { collaboration and } \\
\text { provides support }\end{array}$ & $\begin{array}{l}\text { What kind of } \\
\text { collaboration among } \\
\text { actors in education } \\
\text { encourages the } \\
\text { development of new } \\
\text { activity? }\end{array}$ & $\begin{array}{l}\text { Actors in the } \\
\text { education } \\
\text { system }\end{array}$ & 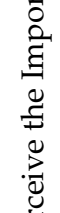 \\
\hline $\begin{array}{l}\text { Teacher as a } \\
\text { professional } \\
\text { leader in their } \\
\text { own field }\end{array}$ & $\begin{array}{l}\text { The behavior of the } \\
\text { learner is formed } \\
\text { when the teacher acts }\end{array}$ & $\begin{array}{l}\text { How do teacher's } \\
\text { professional } \\
\text { experiences and } \\
\text { leadership influence } \\
\text { the organization and } \\
\text { success of distance } \\
\text { teaching/learning? }\end{array}$ & $\begin{array}{c}\text { The teacher and } \\
\text { the learner }\end{array}$ & 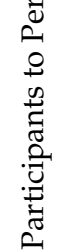 \\
\hline $\begin{array}{l}\text { Discipline, } \\
\text { self-control }\end{array}$ & $\begin{array}{l}\text { Personal discipline, } \\
\text { which has formed } \\
\text { through personal } \\
\text { experience, based on } \\
\text { individuality, concept, } \\
\text { and lifestyle }\end{array}$ & $\begin{array}{l}\text { How is internal and } \\
\text { external discipline } \\
\text { related to the } \\
\text { success of distance } \\
\text { teaching/learning? }\end{array}$ & $\begin{array}{l}\text { Actors in the } \\
\text { education } \\
\text { system }\end{array}$ & 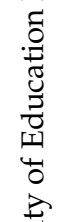 \\
\hline Technical issues & $\begin{array}{l}\text { Influence of hardware } \\
\text { and software }\end{array}$ & $\begin{array}{l}\text { How is the technical } \\
\text { environment linked } \\
\text { to the success of } \\
\text { distance } \\
\text { teaching/learning? }\end{array}$ & $\begin{array}{l}\text { Actors in the } \\
\text { education } \\
\text { system }\end{array}$ & 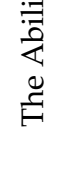 \\
\hline
\end{tabular}

The better communication was ensured, the faster the mobilization of stakeholders in education for distance work was also ensured. In the beginning, they all lacked specific information, and it was not clear what to do. Even if information about the new activity was presented in a concentrated manner and a familiar location, emotional disposition in the state of discomfort impeded perception and assimilation of information. Although the workload of participants in education increased, their attention was already focused on functioning in the new environment, "we worked without counting the working hours. The workload was enormously large. Perhaps we did not even sleep for two weeks" (ST 3). According to the actors in education, the new activity had to be well thought over, weighted, and planned to enable moving to the comfort zone, "the first week was also very difficult to us, and we had to meet face challenges. The children as well. Perhaps two or three more weeks will 
pass, we will work this way, then everything will settle down, and everything will be at its own pace. At a new but known and understandable pace. < . > we'll get back to normal life" (P 5). Transition to the comfort state was related to mutual agreements, coordination of activities, deadlines, and others: "as long as we agreed on video lessons, we had disagreements. Indeed, we have to make joint decisions" (ST 3). The informants searched not only for information, but also for communion.

Need for communion. At the beginning of the new, unfamiliar activity that was introduced during the crisis, the participants in the research distinguished the importance of human communication and relationships with each other, "just communion. It is not without reason that coherence and sustainable communities are much more discussed. This aspect is of utmost significance in this situation in particular. The more in common we have with our colleagues, relatives, the more we share experience, events with them" (UT 7). A simple human relationship was enriched by benevolence and tolerance towards each other, "benevolence towards students" (UT 4); "all we need is goodwill, understanding" (UT 7).

Distance communication provided the necessary information but hindered the maintenance of interpersonal relationships, "it is difficult for teachers to convey information in a distant way when they can't speak with their students live" (S 6). The actors in Lithuanian education stated that they searched for elements of maintaining relationships such as seeing faces on the screen, hearing people's voice, talking informally, and others, "human contact is necessary, even if it is via screen" (UT 2); "maintenance of warm relations, speaking to pupils" (P 9); "I always ask them how they are doing" (UT 7); "it is important to keep the contact. For example, I lead a folk ensemble. Sometimes we contact and communicate via the Zoom program. Not to do or complete something but just to communicate, to hear and to maintain relations" (ST 6); "in the morning I make a Messenger call to them, and I say, "Good morning, the lecture has started." And they start a lecture with joy. I act as a school bell. And I enjoy this when I see these bubbles on the computer clink, clink, clink. Not all the girls hear my call at once, and when they join us, the whole group welcome "helloooooo ... ", "hello, teacher"-we are all together again. This is a sense of unity. We are together. And this is not such a strict discipline. It is necessary to maintain this human approach. It is necessary to introduce certain playfulness, immediacy to prevent people from feeling imprisoned. And then you have to enter them into the work rhythm" (UT 1); "the teacher has to show to the students that s/he accepts their questions in any form, even virtually, that the teacher is ready to help. It is necessary to encourage them to write letters because not all the students have the bravery to do that. On the other hand, students have to ask questions, to show initiative that these lectures are essential to them" (S 10). At the beginning of the new activity, evidence that we are important and necessary to each other was awaited. Without the proof of communion, the education system actors may have gotten disappointed, dissatisfied, or even experienced a sense of pointlessness, "one simple thing is required from students, i.e., to switch on camera. When I don't see what they are doing, I don't understand what I'm doing. They may be drinking coffee or doing something else instead of taking part in the lecture. Sometimes you ask, and there is no answer. It means he or she is not at computer any more... But I can't require such a thing so it is what it is" (UT 6); "if nobody connects, you can plan anything, nothing happens" (UT 8).

Putting the human relation first created a comfortable environment for improvement, where problems disappear when acting together. It was observed that performing in an unfamiliar situation tended to decrease requirements of others, and increased requirements for oneself. Concentration on one's own behavior boosted benevolence towards others, "and I really didn't hear any remarks or complains" (UT 7); "everything in my college is all right. We are understood. There is nothing wrong there < . . > teachers cope with everything" (S 2); "teachers are doing well, we get all the information" (S 6); "teachers have to want to learn technologies, if there are any difficulties $<\ldots>$ In my situation teachers encounter this situation anew, but they cope with this well" (S 1); "students are brilliant people. Perhaps you can ask them for a piece of advice, they will teach you and will help you" (UT 7). The teachers in the new activity strove for proactiveness, participation, and engagement of learners, believing that the only action, moving forward, facilitates learning, "students have to connect and to be ready to work. All the 
rest can be done collectively $<\ldots>$. Probably, their participation is the most important" (UT 8). To attain this, they even tended to lower the requirements. Activity rather than result was important, "while learning it is important not to impose too strict requirements $<\ldots>$ deadlines should be approached more flexibly and requirements should be lowered" (ST 6); "teachers tend to help and to compromise in certain situations, to ease situations $<\ldots$. . Among colleagues as well as among students, the most important thing is to reduce ambitions, to understand that this is not a usual and ordinary situation" (UT 7).

Communion, unity, and the perception of yourself as a community member came through communication. Benevolence towards each other helped with feeling necessary and important, and enhanced initiative, even in a new activity. An unfamiliar activity encouraged the transition from individuality to a sense of community, and simultaneously, to continuous communication. It called for a positive attitude.

Need for positive attitudes. The research participants linked self-activation with internal attitudes, "the most important thing is not to remain indifferent" (S 5); "children should be interested" (P 6); "an appropriate attitude, no fear of change or technologies" (UT 3); "a wish to improve, a wish to cope with challenges" (UT 4); "people's wish to learn" (S 1); "efforts of teachers and students themselves, their attitudes to lectures. Since this is a new thing to everybody, we have to present new ideas how to really make this thing better" (S 3). After the adaptation period was over, confusion reduced, and the importance of individual internal attitudes became evident. The efforts that are necessary for any activity were indicated as important, "person's will" (UT 1) and motivation for a specific activity, "the most important thing is that a student wants to study and to be active, $<\ldots>$ a wish is all that is needed" (UT 2); "it is important for students to have a responsible attitude towards studies when they are organized online just as towards contact studies" (S 6); "teachers should want to learn to use technologies" (S 1). The participants in education noticed that distance teaching/learning required everybody to act independently, setting priorities, indicating individual weaknesses, shortcomings, and strengths, "our children are of such age, when they are happy that mother is at work all the time and they don't have to do anything $<\ldots>$ of course, this independence is desired. There is a bit of this self-dependence, some efforts are seen" (P 2); "pupils have to sincerely be responsible for themselves and to try to learn independently because it is very important. A pupil has to learn, and get used to being responsible for own performed tasks, actions and activities $\langle\ldots\rangle$ this is where we teach pupils to be independent $\langle\ldots\rangle$ now the conditions for that are perfect" (ST 5); "a student has to be able to learn individually, although s/he is supposed to be able to do that already ... " (S 9); "for teachers it is important to have a wish to use new technologies and not to be distanced" (S 5). With the ability to act independently, efforts were significant and provided an opportunity to see the steps of activity and its first results faster, "without any doubts, pupils have to join online lessons to find out what tasks are assigned that day, etc." (ST 2); "students have to join online lectures and be ready to work, $<\ldots>$ because if nobody connects ... you may have the best plans but nothing will happen, $<\ldots>$ then, most probably, the most significant thing is students' participation" (UT 8); "in fact a wish is needed to perform all the tasks because it depends on the child, on his/her attitude to learning. And here, we have distance teaching/learning. You know, there is a significant difference between learning at school and learning online. The child's disposition and efforts are necessary" (P 8); "it is important for teachers to better prepare before a lecture" (S 4); "the very preparation for a lecture is important $\langle\ldots\rangle$ only the information presented during lectures will not give you a full result. Therefore you have to read before it" (S 1). The motivated learners "are always interested in everything" (P 6), and their genuine interest was shown through "the questions asked during lectures" (S 1). Education organizers may have had a positive impact on building positive attitudes towards learning. Communication among stakeholders in education, providing individualized care, and general support is one of the most important objectives in a critical situation. 
Need for supportive collaboration. Parents of minor school-aged children stated that teachers "should also dedicate more time to older school learners" (P 4). The teachers in the country characterized distance teaching/learning through collaboration while taking care of each other, "support, that we gave to help each other $\langle\ldots\rangle$ as it was written in the electronic letter, we should help each other and not disturb the main departments. Many problems can be dealt with by sharing various experiences among colleagues" (UT 7). The crisis provided conditions for perceiving the exchange of good experiences in a different, more simple, and ordinary way. Personal, professional experience and the results of conducted research showed the teachers' transformation of understanding of good experience dissemination. It was as if they rediscovered that not only new ideas, but also daily experiences can be shared. Knowledge of how others work or act allowed for choosing whether to follow them or to make individual solutions, "there were very interesting examples $<\ldots>$ I saw how others do this, but I decided not to do the same, I decided to do differently, and I did so" (UT 1). The research participants noticed that communication according to the individual need was undoubtedly useful, but communication was also necessary among groups of different levels, "general school conception, communication within the community" (ST 7); "perhaps collaboration is the most important thing: administration, teachers, parents, and colleagues. This is the only thing. If everybody agrees among themselves, a lot can be achieved" (ST 4). Mutual assistance while collaborating was observed among learners and parents of minor pupils, "parents communicate and consult each other $<\ldots .>$ classmates write to each other and clarify the topic" (P 4); "it is important not to be silent but to communicate" (P 9). Thus, dissemination of information and good experience should occur not only horizontally but also vertically. The relation between the teacher and the learner is of importance, "the student should see the teacher. To decrease the level of student's anxiety, s/he has to see who s/he is interacting with ...." (UT 2); "a student has to be encouraged to be active all the time. The teacher has to encourage students because if the teacher does not care, they won't connect. They will say: oh, it is not important" (UT 2); "every time to check every task that is assigned and to do this on time. Pupils have to get feedback because they grasp the system and know what is necessary" (ST 5). The interaction between the teacher and the learner builds up the personality and, thus, it performs a more important role than just assimilation of new information.

Need for the teacher as a professional and a leader in the field. Higher education teachers see a direct connection between the success of distance teaching/learning and the teachers' professionalism and previous experience, "professionalism and subject-specific knowledge" (UT 4). Teaching face-to-face was perceived as proper preparation for working online, "definitely a certain teaching experience is necessary. For example, a person who has started teaching gets distance and contact studies. It is complicated. I think some experience in contact studies is also needed" (UT 4). Teachers with more varied experience could easier avoid confusion in changing conditions. The university teacher's professionalism was acquired through experience, "however, this is the teacher's work and experiences more because s/he knows best the taught subject, is aware of the system and of what to expect from students. There are a lot of and various specialties, so it is necessary to be awar" (UT 6). The teacher plans learning and indicates the learning conditions, "good planning is not only about what I'll present but also how I will present at the same time considering the time" (UT 8); "everything starts with the teacher: how s/he presents information, how s/he devices plans, what requirements are set, $\langle\ldots\rangle$ how all this is distributed $<\ldots>$ how it is organized" (UT 1); "seeking to teach something, you have to plan your lessons very well" (ST 5). "The teacher's planning in advance" contributes to success in distance learning (S 7). The expectations of parents and school learners were the same, "it is important for teaching forms, agreements and used platforms to remain the same but most probably they will not. For example, one teacher asked to communicate on one platform; another wanted a different one. Well, such a situation is complicated for children and parents" (P 8). Smart flexibility considering the changed form of communication was desired, "the most important thing is, most probably, is for teachers to be able to convey information online, when they cannot speak to students live" (S 6). The learners expected high-quality information from their teachers and allocated considerable attention to the attractiveness of information 
presentation. In the period of technology development, it was expected that a teacher, as a professional, would search for new ways of teaching that better responded to the needs of the young generation, "perhaps a well-developed ability to use tools, which are used for lectures. $\langle\ldots\rangle$ I would like to emphasize that this requirement applies to the teacher more. It is important for a student as well but more for a teacher" (S 9); "perhaps the teacher's contribution to work. If school teachers used any online programs, it would be easier for children and easier for parents as well. To enable a child to understand assignments and what to do with them because now the information is meant for parents only" (P 2). The informant revealed a constant search for the best solutions, "the lessons should be very interesting to evoke children's interest, to encourage them attend and listen" (P 1); "the teachers may tend to teach in this old or usual ways just like teaching face-to-face. I think these simple methods should not be the only ones. This virtual teaching is the best thing at this period and in this century" (S 5); "the teacher has to encourage new ways of information presentation, to search for new solutions $<\ldots>$ if children are not interested, they will not listen. It has to be this way. It is necessary to evoke their interest and not only in distance learning" (P 1). Teachers who do not search for new, more attractive ways of information presentation that are more acceptable and understandable to learners fail to maintain the necessary interaction and impose too much responsibility for learning on the learners' parents. The teacher's didactic resourcefulness contributes to retaining the teacher-learner interaction, which is the primary condition for teaching/learning, especially at school.

The informants' responses highlighted the need for trusting the teacher's professionalism and providing freedom of action. Distance teaching/learning that unexpectedly "befell" us all has to provide the teacher with the freedom to plan and implement the educational process as flexibly as possible, "all the rest is the teacher's ingenuity and creation" (ST 2); "the university teacher has to have the freedom to finish the lecture whenever s/he wants. Let us say, to disconnect after an hour instead of staying online all the assigned time" (S 7); "the requirements are slightly lower now because the assessment process is held online now and there are no conditions for ensuring academic honesty. Different or more complex questions are given, which require more thinking rather than just providing information. Or smaller-scale tests are assigned or a different learning strategy is applied" (S 4).

Need for discipline and self-control. Transition to distance learning introduced additional disturbances, "being in the lecture, you can hear more. When you learn at home, there are possibilities for getting distracted. To take a computer, for examplewhile listening to the lecture, you can twitch on another program, social networks, and they may distract you. Thus, you need more effort to concentrate and get distanced from the surrounding" (S 4). The informants pointed out the importance of discipline in mobilizing themselves and others for successful activities. Self-control provided conditions for becoming disciplined to the surroundings as well, "not to get panicked and to keep a calm attitude towards everything $\langle\ldots\rangle$ when parents get panicked, then children automatically get panicked too $<\ldots>$ what is going to happen and how $<\ldots>$ I say, stay calm $<\ldots>$ stay calm and wait patiently $<\ldots>$ just to move forward in small steps and not to try to do a huge amount of work during one day to make everything smooth" (P 4). Self-control starts with self-agreement: conscious work and communication with selfestablished favorable conditions for stabilization and the start of activities. The research participants pointed out that discipline is important to everybody: to students, university teachers, school teachers, and parents who help their school-aged children to learn online, "to identify the rhythm for work" (UT 1); "the discipline for a child has to be present at home" (P 8); "a student has to have a high degree of discipline" (UT 1). One informant provided an example of personal life to illustrate self-discipline, "together with my husband we planned our life during the quarantine $<\ldots>$ at eight o'clock, we watch two episodes of series, just two episodes and strictly at 8 o'clock, strictly two episodes. Not more, not fewer, not earlier and not later. The time comes, we leave everything, and it does not matter how you feel, what you are doing, etc. You have to keep to the agreement. This helps; you get disciplined and plan everything. The time for coffee, the time for work, the time for relaxing " (UT 1). It is essential to know where and what you have to do 
and well as others, "it is necessary to think over the load for pupils because $<\ldots>$ a pupil cannot spend $8 \mathrm{~h}$ doing homework. The workload and once again the workload. You have to plan" (ST 3). While planning activities, it is essential to plan time, "we all have to carefully plan time" (UT 1); "you have to take into consideration the time you have $\langle\ldots\rangle$ lectures also know last forty minutes $\langle\ldots\rangle$ it is very very important to take into account time" (UT 8). Distance teaching/learning not only moved to the virtual space but also required different principles of work, which, consequently, called for a new understanding of how to appropriately and effectively use time. Discipline is perceived as a multi-layered phenomenon: I discipline myself, I discipline others (a lecturer influences students' behavior), I discipline activities (administration plans, administrates the process of distance learning).

Technical issues. The actors in education consider equipment and means that provide conditions for virtual functioning as an element of successful distance teaching/learning, "it is most important to be well technically provided for. Pupils have to have internet and computers. Teachers also have to have everything for online communication. If equipment is not available, you can think of a perfect lesson, but you cannot do anything else" (ST 2); "it is important to ensure the proper functioning of systems and softwar" (P 1); "perhaps that everybody has technical equipment and is able to connect and be together" (P 6). Technical and software problems not only create discomfort, but also prevent acheiving the set goals and take away the possibility for action, "very frequently the connection is disturbed" (P 1); "sometimes technologies slightly fail, and it becomes difficult to understand when there are video or audio disturbances. Conversation may not develop so well" (S 1). In the current situation, the virtual space is the only space for activity expression. A system for functioning should be developed that regulates responsibilities. The learners express a wish that teachers should arrange the necessary information in the system in advance. However, technical issues were not distinguished in informants' responses and occupied only a small share of their reflections.

\section{Discussion}

The research results revealed how stakeholders in Lithuania's education process perceive the implementation of distance teaching/learning under quarantine conditions. The main aspects of distance learning, which the informants pointed out, are presented in Figure 1.

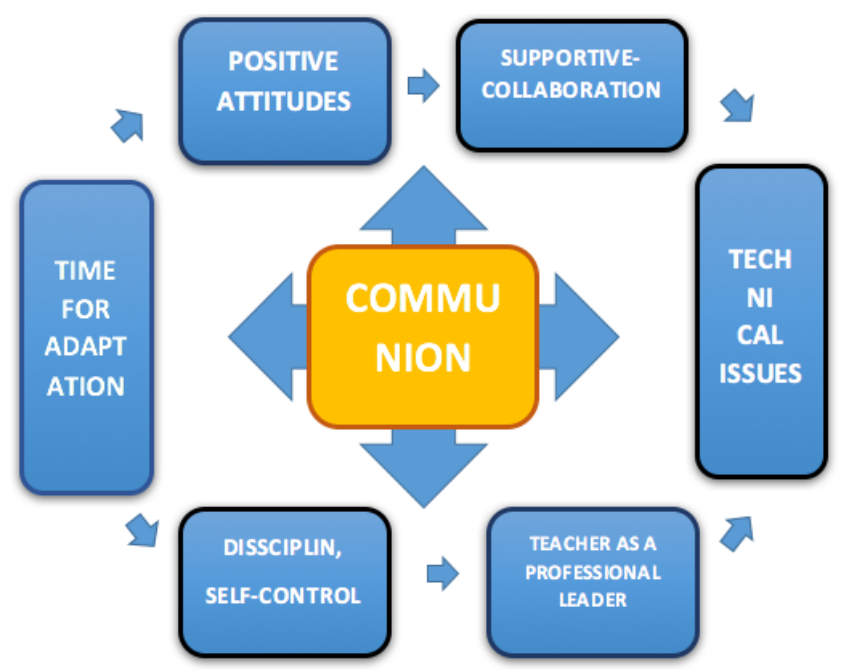

Figure 1. The main aspects of distance teaching/learning during the pandemic (prepared by the authors).

Figure 1 demonstrates the whole picture of the categories and their hierarchical dependence. Firstly, the need for time for adaptation was identified. After the adaptation period, the categories of positive attitudes, supportive collaboration, discipline, and self- 
control, the need for professional leadership supportive collaboration was defined. All the categories were united by communion, which was identified as a strongly pronounced dimension during the crisis. The category of technical issues is the last in the row. All the previous categories have help (or could have helped) solve the technical issues. The analysis of links among categories showed that after the transition to online learning during the pandemic, the dimension of communion and supportive collaboration acquired significance among actors in education. The categories distinguished in the responses of research participants were observed at all the levels of education and ensured the successful activities of actors in the education process in distance learning. The informants' interviews highlighted the significance of communication and communion at the beginning of a crisis. There emerged a need for communion and mobilization for joint activities in the critical situation when performing new activities, even in the individualistic Western society. The necessity for providing help and care appeared, and the possibility of coping more easily with difficulties together was pointed out. Human relations became of paramount importance. A preliminary qualitative inquiry of Japanese students in the early stage of the pandemic revealed that social connection is critical for creating and enhancing learning opportunities [1]. This was in line with the ideas of Smoyer et al. [18], who emphasize the importance of social connection, particularly in the context of emergency teaching. The majority of scientific studies provide for the relevance of the teacher and the relation with them in the technology-mediated process of learning [47-49]. In the crisis, relations gain even more considerable importance [18], and the need for all the learning process' parties, including the children's parents, emerges. Gigliotti [4] claims that "incidents and emergencies happen, but crises are created through communication-and it is through communication that they must be addressed". Schut et al. [50] found that high levels of teacher communion positively impacted the perception of learning assessment, particularly in relations in which teachers' agency was less dominantly exercised. Findings from a study by Smoyer et al. [18] showed that remote learning shapes the interpersonal relationships and communication critical to building students' sense of classroom belonging, engagement, and learning. They examined student feedback about educational experiences during the 2020 COVID-19 pandemic and indicated that class structure and instructor communication positively affected the building of community. It allowed students to be seen and known by others. These efforts bolstered their engagement with the class and kept them motivated.

Our research revealed an interesting phenomenon when actors in the education process became more demanding of themselves than others in a crisis. The analyzed research data indicate tolerance towards others or even gratitude and support. This is an exceptional manifestation of relation with the community in the individualistic society. A theoretical implication, the Gigliotti [4] study results, draw our attention towards the construction of crisis and the role of communication in shaping how these crises are experienced. In the crisis, the participants in our research wanted to be informed about the activity itself and the resulting situation, which sought to reduce the level of anxiety. Milman [51] emphasizes that "frequent, straightforward, and honest communication is essential. Not only does it address questions the students and families might have, but it also gives assurance that management staff has a plan-even if it is evolving". Our research clearly showed that the informants wanted clarity and precise instructions, whereas the state of discomfort hindered the perception and assimilation of information. At the beginning of the lockdown, some kind of personal attention and care was necessary. Individual care shortened the period of adaptation and created a certain emotional comfort. The lack of human interaction is challenging during a pandemic [18]. Absence or shortage of care to meet individual needs caused lower self-confidence and reduced initiative among the research participants, which negatively influenced their attitude towards learning during the pandemic. Thus, institutional support, including appropriate training, is essential for faculty members to comfortably engage in online teaching [52]. 
Our research revealed that a period of adaptation is needed to start a new activity. Our research participants referred to such a period as necessary for emotional mindset and self-empowerment to act in a new situation. Tavares et al. [22] found in their study that most individuals considered that adapting to working online during the COVID-19 pandemic was easy or very easy, and that it happened quickly. Authors recommend ensuring that teleworking occurred during regular working hours to maintain focus and concentration and manage time well. The results of our research coincided with those of Tavares et al. [22], who claimed that the main difficulties encountered in teleworking were the lack of interaction/professional communication with co-workers; the lack of support infrastructure resources, such as the internet or a printer; and reconciling teleworking with family life, household chores, dedication to children, and time/schedule management. Thus, at the beginning of the new activity, all the necessary information must be provided, considering that this stage is significant. School leaders should work with faculty, staff, and other school leaders [51]. School leaders, teachers should not only provide information about the situation and about further actions, but also engage community members in decision-making, "When possible and relevant, a diverse range of voices must be included in decision-making; this will not only recognize their roles as part of the learning community but also foster buy-in" [51]. Such a tendency is also observed under normal learning conditions; there is a shift from a single teacher/single education system to more collaborative planning [53].

One more dimension that was revealed in the research referred to the importance of cheerful personal disposition in facing the crisis. The informants indicated a positive attitude as an essential factor contributing to successfully coping with a critical situation. However, an internal positive attitude towards distance learning does not ensure the individual's active participation and success. Communication plays a crucial role here. Courses that lacked personal communication and interaction inhibited students' ability to stay engaged and motivated [18]. Communication while instructing, which introduces clarity, and constant identification of needs can contribute to success. Bubb and Jons [3] gathered the views of those involved in home-schooling during a pandemic: school leaders, teachers, pupils, and parents [3]. The study showed the satisfaction of all participants. The best evidence of satisfaction is as follows, "Fantastic teachers in this class who are just a phone call away if we as guardians are wondering about something! Cannot praise them enough!". This quote perfectly shows that the availability of teachers is necessary. All the education stakeholders need maintenance of motivation, encouragement, and the creation of favorable conditions to act [54]. Our research disclosed the importance of constant enhancement of motivation. Collaboration of the actors of education help to retain motivation and to mobilize for a new activity. It is a unique opportunity to learn from and with one another, and not just within one's district or state [51]. Redistribution of social roles was noticed in the crisis during the COVID-19 pandemic quarantine. Academic titles, professional merits, and working experience became secondary. Mobilization, positive attitudes, and communion were prioritized.

The difficulties related to time planning emerged during the research in the dimension of self-control and discipline. A new activity, i.e., distance teaching/learning, was unfamiliar and, therefore, it was complicated to plan one's own time and that of others. However, planning itself is significant. When working online, distance is ignored, and the employee's technical profile and self-discipline are essential in the employee's profile to develop the work efficiently and effectively [55]. Inappropriate planning of time leads to a failure to implement educational goals in the lesson/lecture and increased workload for teachers and learners. It is crucial to establish routines and schedules for virtual conferences, meetings, and communications [51].

The research showed that the participants expected competent leadership from the teacher during the critical period of learning. Our study was consistent with previous research efforts regarding teacher leadership's role-individually or collectively-in influencing colleagues and school communities to enhance teaching and learning practices [56]. 
The lack of teacher leadership transfers responsibility for learning on the parents' shoulders or the learners themselves. Then, tension-caused fatigue and particular distractions may appear.

Exceptional attention in distance teaching/learning should be focused on information presentation while searching for more understandable and attractive methods for learners. The research showed that such a search requires providing the teacher with freedom of action and as little control as possible. Stickney, Bento, and Aggarwal [52] found in their study that higher education faculties who teach online satisfaction are more likely if there is appropriate training and if teaching online allows for flexibility in their schedules.

When striving for successful activities in the virtual environment, all the actors' prior preparation in the education process is necessary. However, online teaching/learning preparation in advance is linked more with technical than academic readiness. The smoother the functioning of the used platform, software, and hardware is, the more favorable learning conditions are ensured.

\section{Conclusions}

The research allows for concluding that, after a successful transition to distance learning, the dimensions of communion and supportive collaboration acquired importance among stakeholders in education. That ensured the successful activities of participants in distance learning. Our research showed that the adaptation period was necessary at the beginning of the new activity. The research participants referred to the necessity of such a period for emotional mindset and self-empowerment under new conditions. All the education actors needed enhancement of motivation, encouragement, and establishment of appropriate conditions for activity. The research highlighted self-control and discipline, which embraced the necessity of time planning and related difficulties. Therefore, it is crucial to establish routines and schedules.

It was identified that competent leadership was expected from the teacher during the critical period in learning. According to the informants, the teacher needs freedom of action and little control for leadership to be revealed.

Preparation of all the actors in the education process was needed when seeking to act in the virtual space and advance successfully. Technical rather than academic preparation was emphasized; however, relatively little attention to technical issues and technical disturbances was allocated in the informants' reflections.

This education system stockholder's reflections on educational experiences during the 2020 COVID-19 pandemic reflect and expand upon the existing literature about online education in a crisis. The results cannot be understood as an evaluation of online learning, since the participants were suddenly placed in an unfamiliar environment, which was a new experience. However, the data do offer a window into online teaching dynamics in a crisis and experiences with new activities as key to success.

\section{Limitations}

The research aimed at a general and quick overview of how stakeholders in education perceive a rapid transition to distance learning. The pupils were not included in the research because, due to isolation, it was impossible to get permission from the parents. The responses of separate groups of stakeholders in education were not compared. The reasons that could have conditioned such an opinion of informants were not analyzed either. The summary of the characteristics of the participants was provided in the methods section. However, the socioeconomic background of parents was not investigated.

Further research could include the responses to the same question after a certain period when the system has settled down. With the help of quantitative and qualitative research, it would help to identify where separate groups in the education system (university teachers, parents, teachers, pupils, and their parents) see possibilities for improving distance and hybrid learning. Further research could focus on how communion and sup- 
portive collaboration develop further and to what extent this aspect remains important or becomes more important than other aspects that contribute to coping with a crisis.

The study aimed to carry out a descriptive, exploratory study with variation-based generalization. Therefore, future research should be focused on the communicative generalization and theorization of the study.

Author Contributions: Conceptualization, I.V., Ž.S.-P., and R.K.; methodology, formal analysis, I.V.; resources, I.V., Ž.S.-P., and R.K.; data curation, I.V. and Ž.S.-P.; writing-original draft preparation, I.V., Ž.S.-P., and R.K.; writing—review and editing, Ž.S.-P.; visualization, I.V. All authors have read and agreed to the published version of the manuscript.

Funding: This research received no external funding.

Institutional Review Board Statement: Not applicable.

Informed Consent Statement: Informed consent was obtained from all subjects involved in the study. The study was conducted according to the guidelines of the Declaration of Helsinki. Ethical review and approval was not necessary.

Data Availability Statement: The data presented in this study are available on request from the corresponding author.

Conflicts of Interest: The authors declare no conflict of interest.

\section{References}

1. Ando, D. University teaching and learning in a time of social distancing: A sociocultural perspective. J. Hum. Behav. Soc. Environ. 2020, 1-14. [CrossRef]

2. Bataineh, K.B.; Atoum, M.S.; Alsmadi, L.A.; Shikhali, M. A Silver Lining of Coronavirus. Int. J. Inf. Commun. Technol. Educ. 2021, 17, 138-148. [CrossRef]

3. Bubb, S.; Jones, M.-A. Learning from the COVID-19 home-schooling experience: Listening to pupils, parents/carers and teachers. Improv. Sch. 2020, 23, 209-222. [CrossRef]

4. Gigliotti, R.A. The perception of crisis, the existence of crisis: Navigating the social construction of crisis. J. Appl. Commun. Res. 2020, 48, 558-576. [CrossRef]

5. Estes, C.L. Social Security: The Social Construction of a Crisis. Milbank Mem. Fund Q. Health Soc. 1983, 61, 445. [CrossRef] [PubMed]

6. Voss, M.; Lorenz, D.F. Sociological foundations of crisis communication. In The Handbook of International Crisis Communication Research; Schwarz, A., Seeger, M.W., Auer, C., Eds.; John Wiley \& Sons: New York, NY, USA, 2016; pp. 45-55.

7. Mitroff, I.I. Crisis Leadership: Planning for the Unthinkable; Wiley: New York, NY, USA, 2004.

8. Coombs, W.T. Assessing online issue threats: Issue contagions and their effect on issue prioritisation. J. Public Aff. 2002, 2, 215-229. [CrossRef]

9. Levy, R.A. A Crisis-Oriented Community Clinic. Psychiatr. Serv. 1965, 16, 336-338. [CrossRef]

10. Fingerhut, H. Republicans Skeptical of Colleges' Impact on U.S., but Most See Benefits for Workforce Preparation. 2017. Available online: http:/ / www.pewresearch.org/facttank/2017/07/20/republicans-skeptical-of-colleges-impact-on-u-s-but-most-seebenefits-forworkforce-preparation/ (accessed on 13 September 2020).

11. Cowen, S.; Seifter, B. Winnebagos on Wednesdays: How Visionary Leadership Can Transform Higher Education; Princeton University Press: Princeton, NJ, USA, 2018.

12. Calderon, V.J.; Jones, J.M. Many Higher ed Business Chiefs Fear Financial Future. 2017. Available online: https: / / news.gallup. com/opinion/gallup/215006/higher-businesschiefs-fearfinancial-future.aspx (accessed on 29 September 2020).

13. Farber, B.A. Stress and Burnout in Suburban Teachers. J. Educ. Res. 1984, 77, 325-331. [CrossRef]

14. Van Droogenbroeck, F.; Spruyt, B.; Vanroelen, C. Burnout among senior teachers: Investigating the role of workload and interpersonal relationships at work. Teach. Teach. Educ. 2014, 43, 99-109. [CrossRef]

15. Spilt, J.L.; Koomen, H.M.Y.; Thijs, J.T. Teacher Wellbeing: The Importance of Teacher-Student Relationships. Educ. Psychol. Rev. 2011, 23, 457-477. [CrossRef]

16. Klassen, R.M.; Perry, N.E.; Frenzel, A.C. Teachers' relatedness with students: An underemphasized component of teachers' basic psychological needs. J. Educ. Psychol. 2012, 104, 150-165. [CrossRef]

17. Wang, M.; Ma, W.; Shi, J.; Zhu, Y.; Lin, Z.; Lv, H. Characterization of the key aroma compounds in Longjing tea using stir bar sorptive extraction (SBSE) combined with gas chromatography-mass spectrometry (GC-MS), gas chromatography olfactometry (GC-O), odor activity value (OAV), and aroma recombination. Food Res. Int. 2020, 130, 108908. [CrossRef]

18. Smoyer, A.B.; O’Brien, K.; Rodriguez-Keyes, E. Lessons learned from COVID-19: Being known in online social work classrooms. Int. Soc. Work. 2020, 63, 651-654. [CrossRef] 
19. Brok, P.D.; Brekelmans, M.; Wubbels, T. Interpersonal Teacher Behaviour and Student Outcomes. Sch. Eff. Sch. Improv. 2004, 15, 407-442. [CrossRef]

20. Cornelius-White, J. Learner-Centered Teacher-Student Relationships Are Effective: A Meta-Analysis. Rev. Educ. Res. 2007, 77, 113-143. [CrossRef]

21. Veldman, I.; van Tartwijk, J.; Brekelmans, M.; Wubbels, T. Job satisfaction and teacher-student relationships across the teaching career: Four case studies. Teach. Teach. Educ. 2013, 32, 55-65. [CrossRef]

22. Tavares, F.; Santos, E.; Diogo, A.; Ratten, V. Teleworking in Portuguese communities during the COVID-19 pandemic. J. Enterprising Communities People Places Glob. Econ. 2020. [CrossRef]

23. Thulin, E.; Vilhelmson, B.; Johansson, M. New Telework, Time Pressure, and Time Use Control in Everyday Life. Sustainability 2019, 11, 3067. [CrossRef]

24. Lee, J.; Hernandez, P.M.; Marshall, I., Jr. Review of Online Education in Social Work Programs. J. Evid. Based Soc. Work 2019, 16, 669-686. [CrossRef]

25. Albashtawi, A.H.; Al Bataineh, K.B. The Effectiveness of Google Classroom among EFL Students in Jordan: An Innovative Teaching and Learning Online Platform. Int. J. Emerg. Technol. Learn. 2020, 15, 78. [CrossRef]

26. Tashiro, A.; Shaw, R. COVID-19 Pandemic Response in Japan: What Is behind the Initial Flattening of the Curve? Sustainability 2020, 12, 5250. [CrossRef]

27. Kitayama, S.; Park, J. Is Conscientiousness Always Associated With Better Health? A U.S.-Japan Cross-Cultural Examination of Biological Health Risk. Pers. Soc. Psychol. Bull. 2021, 47, 486-498. [CrossRef]

28. Tracy, S.J. Qualitative Research Methods: Collecting Evidence, Crafting Analysis, Communicating Impact; Wiley Blackwell: Hoboken, NJ, USA, 2020.

29. Akerlind, G.S. A new dimension to understanding university teaching. Teach. High. Educ. 2004, 9, 363-375. [CrossRef]

30. Patton, M.Q. Qualitative Research \& Evaluation Methods, 3rd ed.; Sage Publications, Inc.: Newbury Park, CA, USA, 2002.

31. Bruce, C. The Seven Faces of Information Literacy; Auslib Press: Adelaide, Australia, 1997.

32. Bowden, J.A. Reflections on the phenomenographic team research process. In Doing Developmental Phenomenography; Bowden, J.A., Green, P., Eds.; RMIT University Press: Melbourne, Australia, 2005; pp. 11-31.

33. Walker, C. Learning to learn, phenomenography and children's learning. Educ. Child Psychol. 1998, 15, 25-33.

34. Marton, F. Phenomenography: A research approach to investigating different understandings of reality. J. Thought 1986, 1, 28-49.

35. Marton, F. Phenomenography. In International Encyclopaedia of Education; Husen, T., Postlethwaite, T.N., Eds.; Pergamon Press: Oxford, UK, 1994; pp. 4424-4429.

36. Stenfors-Hayes, T.; Hult, H.; Dahlgren, M.A. A phemenographic approach to research in medical education. Med. Educ. 2013, 47, 261-270. [CrossRef] [PubMed]

37. Wilhelmsson, N.; Dahlgren, L.O.; Hult, H.; Scheja, M.; Lonka, K.; Josephson, A. The anatomy of learning anatomy. Adv. Health Sci. Educ. 2009, 15, 153-165. [CrossRef]

38. Trigwell, K.; Prosser, M.; Waterhouse, F. Relations between teachers' approaches to teaching and students' approaches to learning. High. Educ. 1999, 37, 57-70. [CrossRef]

39. Smaling, A. Inductive, Analogical, and Communicative Generalization. Int. J. Qual. Methods 2003, 2, 52-67. [CrossRef]

40. Dahlgren, L.; Fallsberg, M. Phenomenography as a qualitative approach in social pharmacy research. J. Soc. Adm. Pharm. 1991, 8, 150-156.

41. Åkerlind, G.S. Variation and commonality in phenomenographic research methods. High. Educ. Res. Dev. 2005, 24, 321-334. [CrossRef]

42. Bevington, G.; Wolcott, H.F. Transforming Qualitative Data: Description, Analysis, and Interpretation. Mod. Lang. J. 1996, 80, 405. [CrossRef]

43. Smith, B.; McGannon, K.R. Developing rigor in qualitative research: Problems and opportunities within sport and exercise psychology. Int. Rev. Sport Exerc. Psychol. 2018, 11, 101-121. [CrossRef]

44. Kvale, S. Ten standard Objections to Qualitative Research Interviews. J. Phenomenol. Psychol. 1994, 25, 147-173. [CrossRef]

45. Entwistle, N. Introduction: Phenomenography in Higher Education. High. Educ. Res. Dev. 1997, 16, 127-134. [CrossRef]

46. Kinnunen, P.; McCartney, R.; Murphy, L.; Thomas, L. Through the eyes of instructors: A phenomenographic investigation of student success. In Proceedings of the Third International Workshop on Computing Education Research, Atlanta, GA, USA, 15-16 September 2007.

47. Xiao, J.; Sun-Lin, H.; Lin, T.; Li, M.; Pan, Z.; Cheng, H. What makes learners a good fit for hybrid learning? Learning competences as predictors of experience and satisfaction in hybrid learning space. Br. J. Educ. Technol. 2020, 51, 1203-1219. [CrossRef]

48. Goyal, E.; Tambe, S. Effectiveness of Moodle-enabled blended learning in private Indian Business School teaching NICHE programs. Online J. New Horiz. Educ. 2015, 5, 14-22.

49. Wang, Q.; Quek, C.L.; Hu, X. Designing and Improving a Blended Synchronous Learning Environment: An Educational Design Research. Int. Rev. Res. Open Distrib. Learn. 2017, 18. [CrossRef]

50. Schut, S.; van Tartwijk, J.; Driessen, E.; van der Vleuten, C.; Heeneman, S. Understanding the influence of teacher-learner relationships on learners' assessment perception. Adv. Health Sci. Educ. 2020, 25, 441-456. [CrossRef] [PubMed]

51. Milman, N.B. This Is Emergency Remote Teaching, Not Just Online Teaching. 2020. Available online: https://www.edweek.org/ ew/articles/2020/03/30/this-is-emergency-remote-teaching-not-just.html (accessed on 26 October 2020). 
52. Stickney, L.T.; Bento, R.F.; Aggarwal, A.; Adlakha, V. Online Higher Education: Faculty Satisfaction and Its Antecedents. J. Manag. Educ. 2019, 43, 509-542. [CrossRef]

53. Hill, M.F.; Eyers, G. Moving from student to teacher: Changing perspectives about assessment through teacher education. In Handbook of Human and Social Conditions in Assessment; Brown, G.T.L., Harris, L., Eds.; Routledge: New York, NY, USA, 2016; pp. 57-76.

54. Valantinaite, I.; Sederevičiūtè-Pačiauskienè, Ž. The Change in Students' Attitude towards Favourable and Unfavourable Factors of Online Learning Environments. Sustainability 2020, 12, 7960. [CrossRef]

55. Gálvez, A.; Tirado, F.; Alcaraz, J.M. “Oh! Teleworking!” Regimes of engagement and the lived experience of female Spanish teleworkers. Bus. Ethics Eur. Rev. 2019, 29, 180-192. [CrossRef]

56. York-Barr, J.; Duke, K. What Do We Know About Teacher Leadership? Findings from Two Decades of Scholarship. Rev. Educ. Res. 2004, 74, 255-316. [CrossRef] 